\title{
METHOD FOR OVERCOMING THE PASSION FRUIT SELF-INCOMPATIBILITY ${ }^{1}$
}

\author{
JOSÉ SEVERINO DE LIRA JÚNIOR ${ }^{2}$, CLÁUDIO HORST BRUCKNER ${ }^{3}$, \\ PEDRO CRESCÊNCIO SOUZA CARNEIRO ${ }^{4}$
}

\begin{abstract}
The methodology of self-pollination of passion fruit flowers at anthesis after stigma excision was proposed. This method was compared with self-pollination procedures at anthesis and at the stage of flower bud. Two genotypes (M7 and N9), propagated by cuttings were studied. Self-pollinations were performed at $1 \mathrm{pm}, 1 \mathrm{pm}$ and $5 \mathrm{pm}$ or $5 \mathrm{pm}$. Fruit set (\%), fruit mass (g), pulp mass (g), pulp/fruit ratio and seed number per fruit were evaluated and compared to fruits derived from M7 x N9 and N9 x M7 crosses. No fruit set was obtained from self-pollination at anthesis, which confirms the self-incompatibility of both genotypes. Self-pollination after stigma excision was the best procedure, reaching average fruit set of 73.61 $\%$ (13 hours) and $81.94 \%$ (double self-pollination at $1 \mathrm{pm}$ and $5 \mathrm{pm}$ ). Although two self-pollinations after stigma excision at anthesis is more efficient, performing only one self-pollination at 1 pm requires less labor. The amount of seeds produced per fruit is satisfactory to generate inbred population.
\end{abstract}

Index terms: Passiflora edulis, pollination, selfing, endogamous progenies.

\section{MÉTODO PARA SUPERAÇÃO DA AUTOINCOMPATIBILIDADE DO MARACUJAZEIRO}

RESUMO - Foi proposta a metodologia de autopolinização de flores de maracujazeiro no estádio de antese, após a excisão do estigma. Este método foi comparado com os procedimentos de autopolinização na antese e no estádio de botão floral, ambos sem remoção do estigma. Dois genótipos (M7 e N9), propagados por estaquia, foram estudados. As autopolinizações foram realizadas às $13 \mathrm{e} 17 \mathrm{~h}$ ou às $17 \mathrm{~h}$. Foram avaliadas a frutificação (\%), massa do fruto (g), massa da polpa (g), relação polpa/fruto e número de sementes por fruto, e comparadas às características de frutos derivados dos cruzamentos M7 x N9 e N9 x M7. Não houve frutificação da autopolinização no estádio de antese, que confirma a autoincompatibilidade dos dois genótipos estudados. A autopolinização após a excisão do estigma é o melhor procedimento, que atinge médias de frutificação de 73,61\%, com apenas uma autopolinização às $13 \mathrm{~h}$, e 81,94 \%, com dupla autopolinização às 13 e $17 \mathrm{~h}$. Contudo, apesar de ser mais eficiente fazer duas autopolinizações, após a excisão do estigma na antese, é menos trabalhoso realizar apenas uma autopolinização às $13 \mathrm{~h}$. A quantidade de sementes produzida por fruto é satisfatória para gerar nova população endogâmica.

Termos para indexação: Passiflora edulis, polinização, autofecundação, progênies endogâmicas.

\footnotetext{
${ }^{1}$ (Paper 074-15). Received March 09, 2015. Accepted April 14,2016.

${ }^{2}$ D.Sc in Genetics and Improvement, researcher at the Instituto Agronômico de Pernambuco (IPA), Recife-PE, Brazil, Avenida General San Martin, 1371, Bongi, 50.761-000, Recife-PE, Brasil. E-mail: lira.junior@ipa.br

${ }^{3}$ D.Sc in Genetics and Improvement, professor at the Federal University of Viçosa (UFV), Department of Plant Science, Avenida P. H. Rolphs, s / n, Campus Universitário, 36.571-000, Viçosa-MG, Brazil. E-mail: bruckner@ufv.br

${ }^{4}$ D.Sc in Genetics and Improvement, professor of the Federal University of Viçosa (UFV), Department of General Biology, Avenida P. H. Rolphs, s / n, Campus Universitário, 36,571-000, Viçosa-MG, Brazil. E-mail: carneiro@ufv.br
} 


\section{INTRODUCTION}

Passion fruit (Passiflora edulis Sims.) is an allogamous plant due to sporophytic selfincompatibility (BRUCKNER et al., 1995). The incompatible pollen tube growth is inhibited at the stigmatic surface (RÊGO et al., 1999; RÊGO et al., 2000). Suassuna et al. (2003) proposed the presence of a gametophytic locus associated with the sporophytic system.

Passion fruit breeding can be done by methods that increase the frequency of favorable alleles through selection procedures such as mass selection, selection with progeny testing, but also by heterosis enhancement with hybrid, synthetic or composite varieties (BRUCKNER et al., 2005).

The development of inbreed lineages is essential to achieve good hybrids. Homozygous contrasting plants are needed to heritage studies. Self-fertilization in passion fruit is hampered due to self-incompatibility.

The overcoming of self-incompatibility barriers has been reported by the use of some procedures such as use of auxin in Theobroma cacao (HASENSTEIN; ZAWADA, 2001), application of $\mathrm{CO}_{2}$ in Brassica campestris (LEE et al., 2001), gibberellin application on stigmas in Eruca sativa (SUN et al. 2005), and self-pollination at bud-stage in mustard (CABIN et al., 1996).

In passion fruit, self-pollination at anthesis did not reach fruit set (BRUCKNER et al., 1995), although some authors (AKAMINE; GIROLAMI, 1959; KNIGHT; WINTERS, 1962; CHANG, 1974) reported small fruit set. Self-pollination at bud stage provided $14.8 \%$ (BRUCKNER et al., 1995) and $16.67 \%$ (RÊGO et al., 2013). Rêgo et al. (2013) obtained $10 \%$ fruit set after double self-pollination at anthesis, with an interval of four hours between them.

Although pollination at bud-stages and double pollination allow self-fecundation in passion fruit, these methods demand considerable labor and time by choosing the appropriate flower development stage and with flower protection to avoid cross-pollination.

This work aimed to propose a more efficient self-pollination method for passion fruit genetic breeding.

\section{MATERIAL AND METHODS}

The study was carried out from October to December 2011 in a greenhouse at the Department of Plant Science, Federal University of Viçosa (UFV), Viçosa, Minas Gerais, Brazil. Two passion fruit genotypes, M7 (LIRA JUNIOR et al., 2014) and N9, belonging to the Passion Fruit Breeding Program of UFV were used in this study.

Semi-hardwood cuttings with three branch nodes propagated the plants. Leafless cuttings were planted in plastic pots $(6 \times 20 \mathrm{~cm})$ at depth of 4 $\mathrm{cm}$, containing commercial propagation substrate. Rooted cuttings were transplanted to $30 \mathrm{~L}$ pots and one branch per plant were vertically conducted on a line up to a $1.8 \mathrm{~m}$ high horizontal galvanized wire. Al lateral shoots were eliminated up to $1.8 \mathrm{~m}$ high. Passing the wire, the main stem was bent down and the formation of secondary branches was allowed.

The methodology of self-pollination at anthesis after stigma excision was proposed. The thickness of the excised layer was approximately $1.5 \mathrm{~mm}$, and the style tissue was pollinated. This method was compared with self-pollination at anthesis and at the stage of flower bud. Selfpollinations were performed at $1 \mathrm{pm}, 1 \mathrm{pm}$ and 5 pm or $5 \mathrm{pm}$.

The experimental design was a factorial design $(2 \times 3 \times 3)$, in randomized blocks with two replicates. Each plot consisted of nine plants with two flowers per plant. The first factor was two genotypes (M7 and N9). The second factor was three self-pollination procedures: pollination at anthesis, pollination at flower bud stage and pollination at anthesis after stigma excision. The third factor referred to three times: self-pollination at $1 \mathrm{pm}, 1 \mathrm{pm}$ and repeated at $5 \mathrm{pm}$, and $5 \mathrm{pm}$.

The chosen floral buttons or open flowers were healthy and well formed. Flowers were bagged before anthesis to avoid undesirable pollination. The pollen of these flower was used to pollinate flowers at anthesis and pollen of other flowers of the same plant was used to pollinate flowers at bud stage. Bud pollinations were made on $40 \mathrm{~mm}$ length buttons. Buttons were transversely opened with the aid of a manual retractable cutter, eliminating together, bracts, petals and fimbriae, preserving the female reproductive system. The anthers were removed, although immature. For stigma excision, flower buds were bagged just hours before opening, and after anthesis. stigmas were excised with the aid of a manual retractable cutter and immediately self-pollinated. The thickness of the excised portion was approximately $1.5 \mathrm{~mm}$. Before cutting, the 
cutter blade was sterilized in $70 \%$ alcohol. Stigmas or pistils without stigmas were pollinated by rubbing dehiscent anthers over them with the help of tweezers. After selfing, flowers and buds were bagged again.

The fruit set was evaluated at 7 days after self-pollination and expressed as percentage. Three fruits at maturity were sampled per plot, about 70 days after self-pollination for evaluation of fruit mass, pulp mass, pulp/fruit ratio and number of seeds per fruit. In some plots, only one or two fruits were available for analysis. The traits of fruits developed of self-pollinated flowers were compared to fruits derived from M7 x N9 and N9 x M7 crosses, obtained outside the experiment.

Fruit set percentage data were transformed into $\sqrt{(Y+0,5)}$, and submitted to factorial analysis of variance and means were compared by Tukey test $(p \leq 0.05)$. The original data of fruit mass, pulp mass, pulp/fruit ratio and number of seeds were submitted to analysis of variance and the mean values of treatment were presented as standard errors of the means. Treatments without fruit set were excluded from the statistical analyses. Statistical analyses were performed with the SAS software (Statistical Analysis System).

\section{RESULTS AND DISCUSSION}

Fruit set was not dependent on the effect of genotypes; however, it was influenced by the effects of self-pollination procedures and the pollination time. The interaction between procedure and pollination time was significant $(\mathrm{p} \leq 0.05)$, indicating that the effects of procedures on the fruit set percentage depended on the time when flowers are self-pollinated (Table 1).

The worst fruit set was obtained from selfpollination at anthesis, which confirms the selfincompatibility of both genotypes studied. The double self-pollination procedure (13 and $17 \mathrm{~h})$ has led to some fruit set, $5.56 \%$ on genotype M7 and $2.78 \%$ on N9. The average fruit set after selfpollination at flower bud stage ranged from $6.94 \%$ (17 hours) to $20.83 \%$ (double self-pollination at 1 pm and $5 \mathrm{pm}$ ). By single self-pollination, the fruit set was better at $1 \mathrm{pm}(13.89 \%)$ than at $5 \mathrm{pm}(6.94$ $\%)$.

Self-pollination after stigma excision was undoubtedly the best procedure, reaching average fruit set of $73.61 \%(1 \mathrm{pm}$ ) and $81.94 \%$ (double selfpollination at ), but excision and self-pollination at $5 \mathrm{pm}$ showed to be damaging, because no fruit set was obtained.
The fruit traits of both genotypes are very similar when produced after cross pollination, around $170 \mathrm{~g}$ per fruit and over 330 seeds per fruit (Table 2). Self-pollination lead to a reduction of fruit traits, mainly in M7 genotype (74.33 g fruit mass, $30.37 \mathrm{~g}$ pulp mass and 58.33 seeds per fruit). There is a tendency for obtaining larger fruits from flowers self-pollinated after stigma excision and two self-pollinations.

RNAase in style in gametophytic selfincompatible system (TAKAYAMA; ISOGAI, 2005) and glycoproteins in stigma cause self-incompatibility reaction (SI) in sporophytic system (HISCOCK; MCINNIS, 2003). When a gametophytic locus is associated to the sporophytic system, as found in Brassica (TOCHIGI et al., 2011) and proposed for Passiflora (SUASSUNA et al., 2003), gametophytic locus acts in certain genotypic combinations, enabling the development of the pollen tube and fertilization when incompatibility is expected (LEWIS, 1994). Even with association between systems, the sporophytic system is considered predominant, with the presence of glycoproteins, causing SI reaction on the flower stigma. The rejection of pollen tube grow of Passiflora occurs predominantly in the stigma (RÊGO et al., 2000).

The highest concentration of glycoproteins in stigma occurs at anthesis (ROBERTS et al., 1979). According to Rêgo et al. (1997), the concentration of self-incompatibility glycoproteins in the stigma of passion fruit increases two days before anthesis until anthesis, when concentration is the highest. Procedures to overcome self-incompatibility were studied in several species. Self-pollination at bud stage, with pollen of flowers at anthesis of the same plant are feasible in Brassica (DEWAN et al., 1998), passion fruit (BRUCKNER et al., 1995; REGGO et al., 2013), cacao (DIAS; KAGEYAMA, 1995). Self-pollination at bud stage aims to enable selffertilization before the glycoproteins reach levels that prevent the development of the pollen tube (ROBERTS et al., 1979). Self-pollinations performed at bud stage resulted in average fruit set of $13.88 \%$ (Table 1). These results are similar to those observed by Bruckner et al. (1995) and Rêgo et al. (2013), respectively of 14.8 and $16.67 \%$, demonstrating the feasibility of selfing at bud stage. However, bud selfing at 5 pm leads to fewer fruit set, compared to bud selfing performed at $1 \mathrm{pm}$. The concentration of glycoproteins probably increases in the stigma over time, possibility suggested by Roberts et al. (1979).

Successive self-pollinations are able to generate self-fertilization probably because the first self-pollination neutralizes glycoproteins, so that 
subsequent pollinations may generate pollen tubes capable of fertilizing the embryo sac. There was no fertilization resulting from self-pollination performed at anthesis at $1 \mathrm{pm}$ and $5 \mathrm{pm}$ in both genotypes. However, when two successive self-pollinations are performed at $1 \mathrm{pm}$ and $5 \mathrm{pm}$, there was a small self-fertilization percentage, $5.56 \%$ on genotype M7 and $2.78 \%$ on N9 (Table 1), confirming the possible neutralization of glycoproteins by the first selfpollination, which enabled a small percentage of fertilization at the second self-pollination. In addition, at the bud stage, two self-pollination increased fruit set from $11.11 \%$ to $19.44 \%$ in genotype $\mathrm{M} 7$, and from $16.67 \%$ to $22.22 \%$ in genotype N9. Shivanna (2012) observed a similar effect in the absence of pollinators. This author described self-fertilization caused by the wind rubbing of anthers on the stigmas of passion fruits in India. These results suggest emasculation in controlled hybridizations, even though passion fruit is self-incompatible, mainly for genetic studies.

Self-pollination held at anthesis but after stigma excision generated the highest fruit set average: $51.85 \%$ (Table 1). The data obtained support the hypothesis that stigma excision can remove glycoproteins, and that pollen is able to germinate and start the pollen tube growth in the style tissues. Two self-pollinations on flowers without stigmas also increased fruit set from $75 \%$ to $83.33 \%$ in M7 genotype and from $72.22 \%$ to $80.56 \%$ in N9 genotype. Stigma self-pollination excised flowers at $5 \mathrm{pm}$, on the other hand, it did not reach fruit set. Probably, some tissue dehydration in the late afternoon avoided pollen germination or pollen tube growth. According to Souza et al. (2004), the stigmatic receptiveness in passion fruit significantly decreases after $5 \mathrm{pm}$, to $55 \%$ in April and $11 \%$, in December, in Brazil. These results show that season and late pollination hour adversely affect fruit set.

Similar fruit set averages (Table 1) indicate that the procedures and scheduled self-pollinations affected M7 and N9 genotypes in the same way. However, fruit mass, pulp mass, pulp yield and number of seeds per fruit derived from selfing differed among genotypes (Table 2). Self-pollination procedures and schedules did not alter significantly fruit traits within each genotype, but the effect of self- fertilizations was more drastic on reducing fruit and pulp mass and the number of seeds per fruit in M7 genotype.

Although means within genotypes were similar, pulp mass and the amount of seeds were somewhat higher when resulting from two selfpollinations (13 and $17 \mathrm{~h}$ ). Both self-pollinations probably made possible the growth of a higher number of pollen tubes, and consequently, higher amount of seeds. Akamine and Girolami (1959) and Hardin (1986) verified correlation between fruit weight and seed number.

Fruits originated from self-fertilizations were smaller and had fewer seeds than fruits of the same genotypes obtained dfrom M7xN9 or N9xM7 crosses (Table 2). The reduction is most noticeable in M7 genotype. These results suggest that there are differences between genotypes in the selfincompatible reaction. According to Hatakeyama (1998), there is a dominance relation among self-incompatibility alleles in sporophytic selfincompatibility and the intensity may vary among alleles according to their degree of dominance. Selffertilizations are important to obtain lineages for the production of commercial hybrids in allogamous plants and for genetic studies. 
TABLE 1- Fruit set percentage reached in two Passiflora edulis genotypes by three times and three selfpollinations methods.

\begin{tabular}{|c|c|c|c|c|c|}
\hline \multirow{3}{*}{ Genotype } & \multirow{3}{*}{ Flower stage and procedure } & \multicolumn{3}{|c|}{ Self-pollination time } & \multirow{2}{*}{ Average } \\
\hline & & $13 \mathrm{~h}$ & $13 \mathrm{~h}$ and $17 \mathrm{~h}$ & $17 \mathrm{~h}$ & \\
\hline & & \multicolumn{4}{|c|}{ Fruit set $(\%)$} \\
\hline \multirow{4}{*}{ M7 } & Anthesis & 0.00 & 5.56 & 0.00 & $1.85^{\mathrm{c}}$ \\
\hline & Bud stage & 11.11 & 19.44 & 8.33 & $12.96^{\mathrm{b}}$ \\
\hline & Excised stigma & 75.00 & 83.33 & 0.00 & $52.77^{\mathrm{a}}$ \\
\hline & Average & $28.70^{\mathrm{Al}}$ & $36.11^{\mathrm{A}}$ & $2.77^{\mathrm{B}}$ & 22.53 \\
\hline \multirow{4}{*}{ N9 } & Anthesis & 0.00 & 2.78 & 0.00 & $0.92^{\mathrm{c}}$ \\
\hline & Bud stage & 16.67 & 22.22 & 5.56 & $14.81^{\mathrm{b}}$ \\
\hline & Excised stigma & 72.22 & 80.56 & 0.00 & $50.92^{\mathrm{a}}$ \\
\hline & Average & $29.63^{\mathrm{A}}$ & $35.18^{\mathrm{A}}$ & $1.85^{\mathrm{B}}$ & 22.22 \\
\hline \multirow{4}{*}{ M7 and N9 } & Anthesis & $0.00^{\mathrm{Bc}}$ & $4.17^{\mathrm{Ac}}$ & $0.00^{\mathrm{Bb}}$ & 1.39 \\
\hline & Bud stage & $13.89^{\mathrm{Bb}}$ & $20.83^{\mathrm{Ab}}$ & $6.94^{\mathrm{Ca}}$ & 13.88 \\
\hline & Excised stigma & $73.61^{\mathrm{Aa}}$ & $81.94^{\mathrm{Aa}}$ & $0.00^{\mathrm{Bb}}$ & 51.85 \\
\hline & Average & $29.16^{\mathrm{B}}$ & $35.64^{\mathrm{A}}$ & $2.31^{\mathrm{C}}$ & 22.37 \\
\hline
\end{tabular}

1/ Same capital letters in the line and lower case in the column mean absence of significant differences (Tukey test, $\mathrm{P} \leq 0.05$ ).

TABLE 2- Fruit mass, pulp mass, pulp/fruit ratio, and seeds per fruit reached in two genotypes of Passiflora edulis by three times and three self-pollination methods

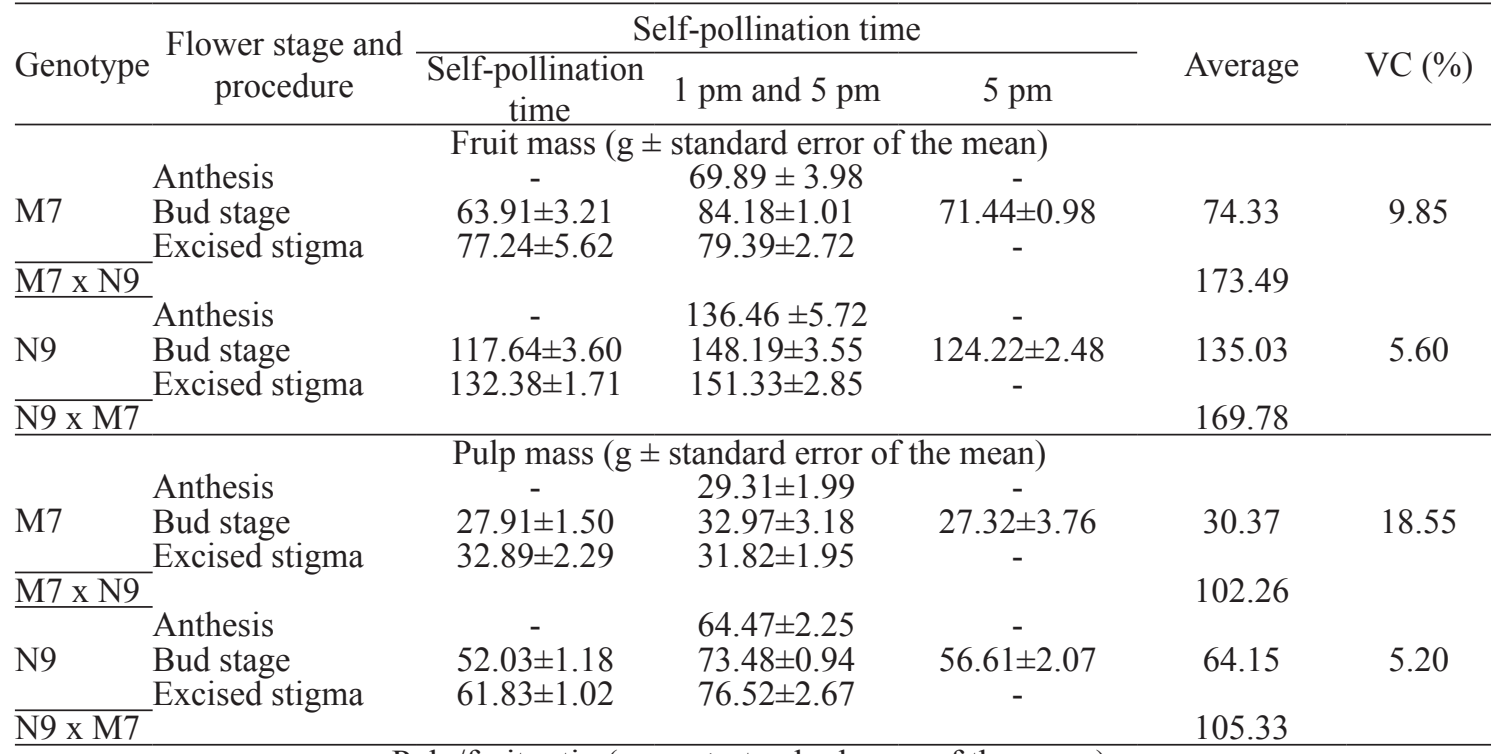

\begin{tabular}{|c|c|c|c|c|c|c|}
\hline N9 x M7 & 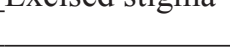 & 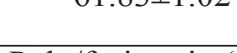 & & & 105.33 & \\
\hline & & Pulp/fruit ratio ( & \pm standard 6 & of the mean) & & \\
\hline & Anthesis & - & $41.93 \pm 2.08$ & - & & \\
\hline M7 & Bud stage & $43.67 \pm 0.57$ & $39.17 \pm 0.52$ & $38.24 \pm 2.24$ & 40.94 & 8.32 \\
\hline & Excised stigma & $42.58 \pm 2.08$ & $40.09 \pm 1.37$ & - & & \\
\hline M7 x N9 & & & & & 60.91 & \\
\hline & Anthesis & - & $47.25 \pm 1.97$ & - & & \\
\hline N9 & Bud stage & $42.22 \pm 2.17$ & $49.58 \pm 2.21$ & $45.57 \pm 1.06$ & 47.31 & 8.22 \\
\hline$\overline{\mathrm{N} 9 \times \mathrm{M} 7}$ & Excised stigma & $46.71 \pm 0.67$ & $50.56 \pm 2.19$ & - & 62.15 & \\
\hline & & Seed number ( $\mathrm{n}$ & \pm standard e & of the mean) & & \\
\hline & Anthesis & - & $59 \pm 2.82$ & - & & \\
\hline M7 & Bud stage & $51 \pm 4.94$ & $66 \pm 4.45$ & $55 \pm 2.82$ & 58.33 & 13.33 \\
\hline & Excised stigma & $58 \pm 2.68$ & $61 \pm 2.28$ & - & & \\
\hline M7 x N9 & & & & & 339.33 & \\
\hline & Anthesis & - & $167 \pm 12.72$ & - & & \\
\hline N9 & Bud stage & $159 \pm 9.89$ & $174 \pm 12.22$ & $142 \pm 9.78$ & 164.33 & 8.74 \\
\hline$\overline{\mathrm{N} 9 \times \mathrm{M} 7}$ & Excised stigma & $159 \pm 4.94$ & $185 \pm 14.84$ & - & 333.66 & \\
\hline
\end{tabular}




\section{CONCLUSION}

The most efficient procedure to obtain selffertilization is to perform two self-pollinations after stigma excision at anthesis. However, less labor is necessary for one self-pollination at $1 \mathrm{pm}$, and the effort is only slightly fewer. Saving time, a higher number of flowers can be handled without the need to preserve and protect extra flowers, or to come back to the same flowers in the late afternoon for the second self-pollination, facilitating the process and minimizing eventual risks of pollen contamination. Seeds yielded per fruit are satisfactory to generate lineages or inbred populations.

\section{ACKNOWLEDGEMENTS}

The authors thank Embrapa for doctoral scholarship and the National Council for Scientific and Technological Development (CNPq) for financial support.

\section{REFERENCES}

AKAMINE, E.K.; GIROLAMI, G. Pollination and fruit set in the yellow passion fruit. Honolulu: University of Hawaii, 1959. 44p (Technical Bulletin, 39).

BRUCKNER, C.H.; CASALI, V.W.D.; MORAES, C.F.; REGAZZI, A.J.; SILVA, E.A.M. Selfincompatibility in passion fruit (Passiflora edulis Sims). Acta Horticuturae, The Hague, v.370, p.45-57, 1995.

BRUCKNER, C.H.; SUASSUNA, T.M.F.; RÊGO, M.M.; NUNES, E.S. Autoincompatibilide de do maracujá - implicações no melhoramento genético. In: FALEIRO, F.G.; JUNQUEIRA, N.T.V.; BRAGA, M.F. (Ed.). Maracujá: germoplasma e melhoramento genético. Planaltina: Embrapa, 2005. p.317-338.

CABIN, R.J.; EVANS, A.S.; JENNINGS, D.L.; MARSHALL, D.L.; MITCHELL, R.J.; SHER, A.A. Using bud pollinations to avoid self-incompatibility: implications from studies of three mustards. Canadian Journal of Botany, Ottawa, v.74, p.285289, 1996.

CHANG, C.C. Studies on unfruitfullness of the yellow passion fruits growing in Taiwan. Taiwan Agriculture Quarterly, Taiwan, v.10, p.78-89, 1974.
DEWAN, D.B.; RAKOW, G.; DOWNEY, R.K. Growth and yield of doubled haploid lines of oilseed Brassica rapa. Canadian Journal of Plant Science, Ottawa, v.78, p.537-544, 1998.

DIAS, L.A.S.; KAGEYAMA, P.Y. Combining ability for cacao (Theobroma cacao L.) yield components under southern Bahia conditions. Theoretical and Applied Genetics, Berlin, v.90, p.534-541, 1995.

HARDIN, L.C. Floral biology and breeding system of the yellow passion fruit, Passiflora edulis $\mathrm{f}$. flavicarpa. Proceedings of the Interamerican Society for Tropical Horticulture, Homestead, v.30, p.35-44, 1986.

HASENSTEIN, K.H.; ZAWADA, M.S. Auxin modification of the incompatibility response in Theobroma cacao. Physiologia Plantarum, Copenhagem, v.112, p.113-118, 2001.

HATAKEYAMA, K; TAKASAKI, T.; WATANABE M.; HINATA, K. Molecular Characterization of S Locus Genes, SLG and SRK, in a Pollen-Recessive Self-Incompatibility Haplotype of Brassica rapa L. Genetics, Bethesda, v.149, p. 1587-1597, 1998.

HISCOCK, S.J.; MCLNNIS, S.M. Pollen recognition and rejection during the sporophytic self-incompatibility response: Brassica and beyond. Trends in Plant Science, Amsterdam, v.8, p. 606613,2003

KNIGHT JR, R.J.; WINTERS, H.F. Pollination and fruit set of yellow passionfruit in Southern Florida. Proceedings of the Florida State Horticultural Society, Bradenton, v.75, p. 412-418, 1962.

LEE, S.H.; HONG, M.Y.; KIM, S.; LEE, J.S.; KIM, B.D.; MIN, B.H.; BAEK, N.K.; CHUNG, Y.Y. Controlling self-incompatibility by $\mathrm{CO}_{2}$ gas treatment in Brassica campestris: structural alteration of papillae cell and differential gene expression by increased $\mathrm{CO}_{2}$ gas. Molecules and Cells, New York, v.11, p.186-191, 2001.

LEWIS, D. Gametophytic-sporophytic incompatibility. In: WILLIAMS, E.G.; CLARKE, A.E.; KNOX, R.B. (Ed.). Genetic control of selfincompatibility and reproductive development in flowering plants. Dordrecht: Kluwer, 1994. p. $88-101$. 
LIRA JR, J.S.; FLORES, P.S.; BRUCKNER, C.H. UFV-M7: mutant yellow passionfruit genotype with photoperiod insensitivity for flowering. Crop Breeding and Applied Biotechnology, Viçosa, MG, v.14, p.128-131, 2014.

RÊGO, M.M.; BRUCKNER, C.H.; SILVA, E.A. M.; FINGER, F.L.; SIQUEIRA, D.L.; FERNANDES, A.A. Self-incompatibility in passion fruit: evidence of two locus genetic control. Theoretical and Applied Genetics, Ribeirão Preto, v.98, p.564-568, 1999.

RÊGO, M.M.; FINGER, F.L.; BRUCKNER, C.H. Expression of pistil-specific proteins associated with self-incompatibility in yellow passion fruit (Passiflora edulis Sims f. flavicarpa Degener). Brazilian Journal of Genetics, Ribeirão Preto, v.20, p.143-143, 1997.

RÊGO, M.M.; RÊGO, E.R.; BRUCKNER, C.H.; FINGER, F.L.; OTONI, W.C. Overcoming selfincompatibility in Passion Fruit by double pollination in anthesis stages. Acta Horticulturae, The Hague, v.1000, p.533-536, 2013.

RÊGO, M.M.; RÊGO, E.R.; BRUCKNER, C.H.; SILVA, E.A.M.; FINGER, F.L.; PEREIRA, K.J.C. Pollen tube behavior in yellow passion fruit following compatible and incompatible crosses. Theoretical and Applied Genetics, Ribeirão Preto, v.101, p.685-689, 2000.

ROBERTS, I.N.; STEAD, A.D.; OCKENDON, D.J.; ANDON, A. Glycoprotein associated with the acquisition of the self-incompatibility system by maturing stigmas of Brassica oleracea. Planta, Berlin, v.146, p.179-183, 1979.
SHIVANNA, K.R. Reproductive assurance through unusual autogamy in the absence of pollinators in Passiflora edulis (passion fruit). Current Science, Bangalore, v.103, p.1091-1096, 2012.

SOUZA, M.M.; PEREIRA, T.N.S.; VIANA, A.P.; PEREIRA, M.G.; AMARAL JR, A.T.; MADUREIRA, H.C. Flower receptivity and fruit characteristics associated to time of pollination in the yellow passion fruit Passiflora edulis Sims f. flavicarpa Degener (Passifloraceae). Scientia Horticulturae, New York, v.101, p.373-385, 2004.

SUASSUNA, T.M.; BRUCKNER, C.H.; CARVALHO, R.; BORÉM, A. Self-incompatibility in passionfruit: evidence of gametophytic-sporophytic control. Theoretical and Applied Genetics, Berlin, v.106, p. 298-302, 2003.

SUN, W.; PAN, Q.; LIU, Z.; MENG, Y.; ZHANG, T.; WANG, H.; ZENG, X. Overcoming selfincompatibility in Eruca sativa by chemical treatment of stigmas. Plant Genetic Resources, Wallingford, v.3, p.13-18, 2005.

TAKAYAMA, S.; ISOGAI, A. Self-incompatibility in plants. Annual Review of Plant Biology, Palo Alto, v.56, p.467-489, 2005.

TOCHIGI, T.; UDAGAWA, H.; LI, F.; KITASHIBA, H.; NISHIO, T.T. The self-compatibility mechanism in Brassica napus L. is applicable to $\mathrm{F}_{1}$ hybrid breeding. Theoretical and Applied Genetics, Berlin, v.123, p.475-482, 2011. 